\title{
Gastric pyogenic granuloma: rare entity, usual therapy
}

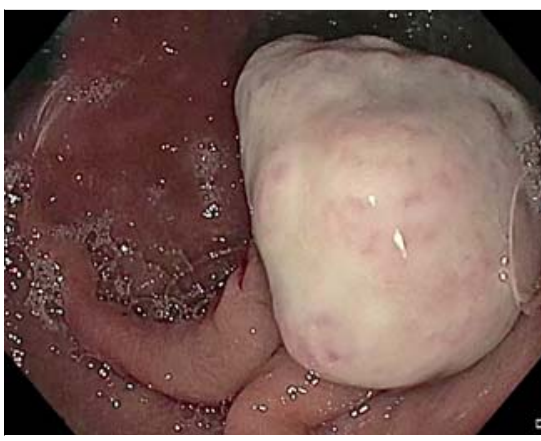

- Fig. 1 20-mm polypoid lesion with a superficial white film covering the head.

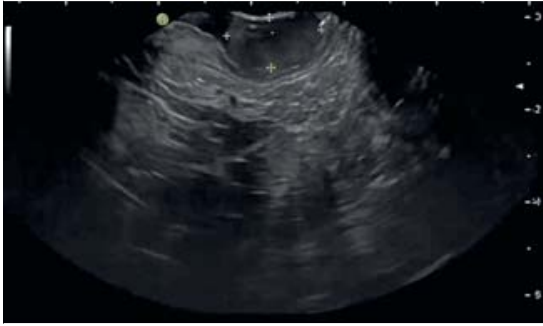

- Fig. 2 Endoscopic ultrasonography evidence of a hypoechoic lesion arising from the second wall layer with preserved wall layers and no deep infiltration.

Lobular capillary hemangioma, known as pyogenic granuloma, is a benign vascular tumor that generally appears on the skin or in the oral cavity but rarely occurs in the gastrointestinal tract, where it can cause bleeding [1]. Although gastric pyogenic granuloma is rarely reported in the literature, (up to 2016, approximately 50 cases of gastrointestinal pyogenic granuloma in the English literature had been indexed on MEDLINE, including a few cases of gastric involvement), the actual incidence is probably higher [2,3].

The endoscopic appearance of pyogenic granuloma is usually a single polypoid lesion, smooth and ulcerated; the color ranges from bluish to reddish with a superficial white or opaque film covering. Resection of pyogenic granuloma is nec-

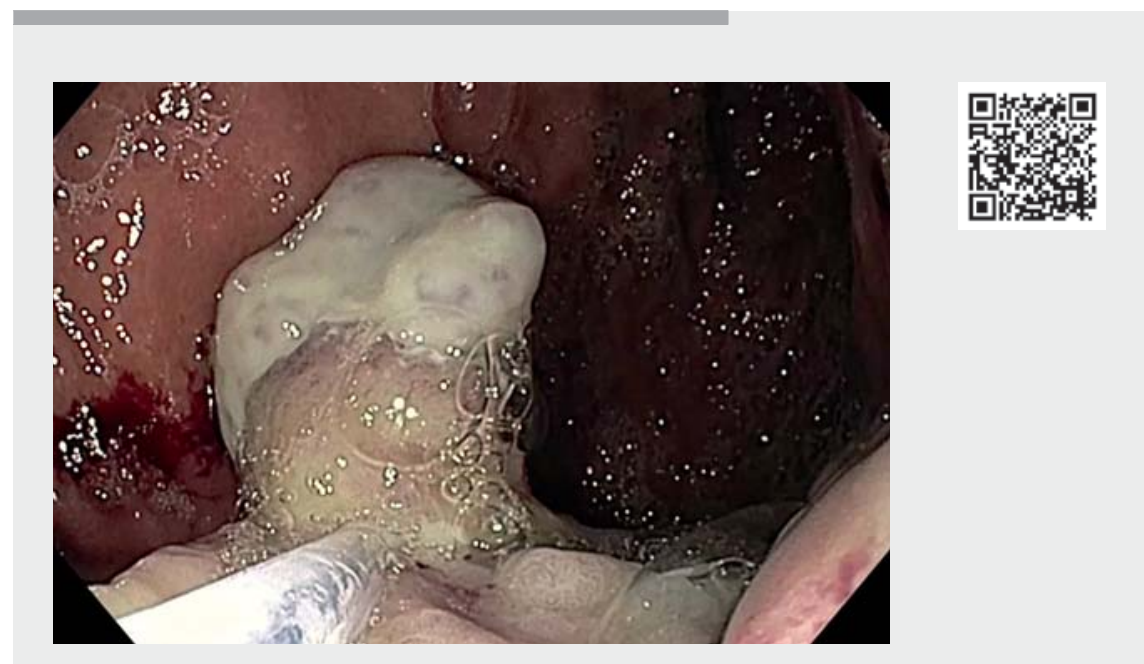

Video 1 Gastric pyogenic granuloma effectively removed by endoscopic snare resection.

essary in patients with anemia, but postresection bleeding is a potential complication. The lesions typically involve the mucosa but may extend to the deep layers; thus, preoperative endoscopic ultrasonography is recommended $[1,4,5]$. Histopathologically, pyogenic granuloma is a hemangioma characterized by a lobule-like growth of capillaries with enlarged vascular endothelial cells and inflammatory cell infiltration in the stroma. Granulation tissue may also be present; the main pathological differential diagnosis of pyogenic granuloma includes bacillary angiomatosis, Kaposi's sarcoma, or inflammatory and/or hyperplastic polyps [1, 3].

We report a case of a 78 year-old Caucasian woman with a medical history significant for ibuprofen use admitted to our department for anemia and melena requiring transfusion. Esophagogastroduodenoscopy revealed a nearly 20-mm pedunculated polyp, strongly hyperemic with a superficial white film, in the gastric body ( $>$ Fig. 1). Endoscopic ultrasonogra-

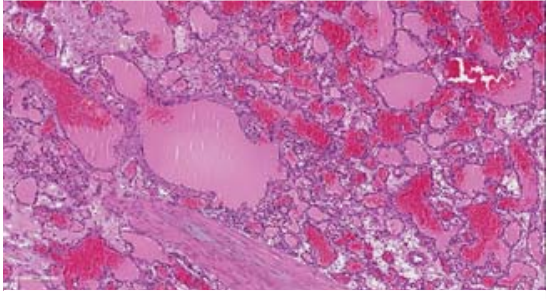

Fig. 3 Numerous thin-walled capillaries of different size lined with endothelial cells are separated by inflammatory stroma (hematoxylin \& eosin, $\times 40$ ).

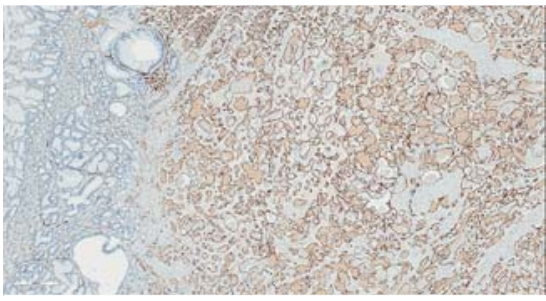

- Fig. 4 ERG positivity, a specific marker for endothelial cells, in contrast with gastric glands, with foveolar hyperplasia surrounding the lesion (immunohistochemistry, $\times 20$ ) 
phy showed mucosal involvement without deep infiltration ( $>$ Fig. 2).

We removed the polyp using endoscopic mucosal resection, lifting the lesion with a solution of indigo carmine and epinephrine; in addition, multiple clips were used to close the defect to prevent bleeding (> Video 1). Histology demonstrated foveolar hyperplasia and lobulated capillary hemangioma, characteristic of pyogenic granuloma (> Fig.3, > Fig.4). Her refractory anemia improved after the procedure.

Endoscopy_UCTN_Code_CCL_1AB_2AD_3AC

\section{Competing interests}

Dr. Cennamo is a consultant for and has received speaker fees and travel grants from Olympus Italia, Olympus Europa, Euromedical, and Novità Medicali. All other authors declare that they have no conflict of interest.

The authors

\section{Marco Bassi ${ }^{1}$, Elisa Righi ${ }^{2}$, Emanuele} Dabizzi ${ }^{1}$, Stefania Ghersi ${ }^{1}$, Pasquale Apolito ${ }^{1}$, Stefano Landi ${ }^{1}$, Vincenzo Cennamo ${ }^{1}$ ()

1 Gastroenterology and Interventional Endoscopy Unit, AUSL Bologna, Surgical Department, Bologna, Italy

2 Anatomic Pathology Unit, AUSL Bologna, Bologna Metropolitan Department of Pathology, Bologna, Italy
Corresponding author

\section{Marco Bassi, MD}

Gastrointestinal and Interventiona Endoscopy Unit, Surgical Department, AUSL Bologna, Maggiore Hospital, Largo Nigrisoli 2, 40139 Bologna, Italy

Fax: +39-05-1647814

m.bassi@ausl.bologna.it

\section{References}

[1] Hayashi Y, Hosoe N, Takabayashi K et al. Clinical and endoscopic characteristics of pyogenic granuloma in the small intestine: a case series with literature review. Intern Med 2020; 59: 501-505

[2] Katsurahara M, Kitade T, Tano S et al. Pyogenic granuloma in the small intestine: a rare cause of obscure gastrointestinal bleeding. Endoscopy 2015; 47: E133-E134

[3] Val-Bernal JF, Mayorga M, Cagigal ML et al. Gastric pyogenic granuloma: report of two cases and review of the literature. Pathol Res Pract 2016; 212: 68-71

[4] Reichert MC, Schuster M, Kim Y] et al. Recurrent gastrointestinal bleeding due to multiple pyogenic granulomas in the stomach. Am J Gastroenterol 2017; 112: 833

[5] Meeks MW, Kamal UM, Hammami MB et al. Gastrointestinal pyogenic granuloma (lobular capillary hemangioma): an underrecognized entity causing iron deficiency anemia. Case Rep Gastrointest Med 2016; 2016: 4398401
Bibliography

Endoscopy 2022; 54: E635-E636

DOI 10.1055/a-1730-4529

ISSN 0013-726X

published online 4.2.2022

(c) 2022. Thieme. All rights reserved.

Georg Thieme Verlag KG, Rüdigerstraße 14,

70469 Stuttgart, Germany

\section{ENDOSCOPY E-VIDEOS}

https://eref.thieme.de/e-videos

回局 Endoscopy E-Videos is an open access online section, 自: reporting on interesting cases and new techniques in gastroenterological endoscopy. All papers include a high quality video and all contributions are freely accessible online. Processing charges apply (currently EUR 375), discounts and wavers acc. to HINARI are available.

This section has its own submission website at

https://mc.manuscriptcentral.com/e-videos 